\title{
ANALYSIS OF COMMUNES' POTENTIAL FALL IN REVENUE FOLLOWING INTRODUCTION OF AD VALOREM PROPERTY TAX
}

\author{
Sebastian Gnat, PhD \\ University of Szczecin \\ e-mail: sebastian.gnat@usz.edu.pl
}

\begin{abstract}
The property tax reform is the subject of numerous discussions and multi-aspect analyses. One of the conclusions from the analyses is an argument referring to the risk of a substantial rise in financial charges imposed on objects of taxation. The replacement of property tax with ad valorem property tax is seen as a potential source of increased revenue for communes. However, some of the communes may experience the opposite effect, i.e. the risk of a revenue loss. Should the tax reform come into force, it will result in protests among the affected local governments. The paper presents the results of a study into the situation of an exemplary commune, where specific conditions that could lead to lowering the commune's revenue due to the introduction of the ad valorem property tax may occur.
\end{abstract}

Key words: ad valorem property tax, mass appraisal.

JEL Classification: $H 2, R 15, R 51$.

Citation: Gnat S., 2018, Analysis of Communes' Potential Fall in Revenue Following Introduction of ad Valorem Property Tax, Real Estate Management and Valuation, vol. 26, no. 1, pp. 63-72.

DOI: 10.2478/remav-2018-0006

\section{Background}

After the period of Polish economic transformation in the early 1990s, discussions about the modification of property taxation commenced. The main concept was to replace property size with its cadastral value as the tax basis. The need to reform the existing methods of taxation has been addressed by many authors who point out that today's forms of property taxation are outdated and ill-suited to modern reality, and fail to accomplish their intended purpose of a wealth tax (ETEL, DOWGIER 2013). It is often signalized that this reform of the property taxation system will strengthen the financial autonomy of local governments, as well as improving their income stability and opportunities for investments in infrastructure (WOŁOWIEC 2003). Researchers dealing with this issue indicate that the ad valorem property tax will help local communities see a clear link between what they expect of local authorities and the sources of funding to pay for these demands. A larger share of local taxes in the total of taxes paid by community members will make them feel that financial resources coming from their contributions are used to meet their needs. Acknowledgement of this relationship will strengthen the conviction that the taxes they pay are reasonable and fair. What is more, "there would be a beneficial effect on local democracy as a result of increased transparency of this source of commune revenue, helping to evaluate the use of resources and enforce the liability of the local government in this respect" (PIEKUT, 2014, p. 88). Property value taxation is a common practice in many countries. The characteristics of individual systems have been outlined by numerous authors (e.g. ETEL (ed.), 2003; MARONA 2006; POLNY 2014). The diversity of solutions and lengthy experience concerning property taxation show that taxes based on property value are effective and socially acceptable. The published analyses of economic conditions allowing for the property tax reform have proven the reform to be justified (see: GŁUSZCZAK, MARONA 2015). However, it should be 
noted that the property taxation reform is a subject of political and scientific debate also in other countries of Central and Eastern Europe. Individual countries of the so-called "Eastern Bloc" are at different stages of the debate and implementation process (see: MiKESELL et al., 2007; HEŁDAK et al., 2014; PINDYK 2016).

Despite numerous attempts to explain to the public the advantages of taxation based on property value, its introduction in Poland is not possible today due to both socio-economic and economicorganizational reasons. As far as ad valorem tax is concerned, the public opinion is clearly negative. There is a lot of concern about the amount of the tax; it is often indicated that the process of calculating the cadastral tax will be complicated and costly. The systems of information about properties are not ready to ensure smooth implementation of the tax reform. There are still plenty of questions, doubts and work to be done on the matter. Problems of an organizational, IT or cost-related nature can be solved in the longer or shorter perspective; however, it is broadly felt that the cadastral tax is going to lead to a dramatic increase in the tax burden. Moreover, there is one more problem associated with the property taxation reform that is rarely addressed in scientific publications or debates -namely the possibility for some communes to face a fall in revenue due to replacing the property tax based on real estate size with the ad valorem tax. Such a situation may take place as a result of two main factors. The first one refers to the ad valorem tax rate, while the second factor is the cadastral value of properties located in individual communes. If, similarly to the present situation, there is a maximum permitted tax rate that can be used by local governments, then, after the reform, communes with a considerable number of cheap properties will be at risk of losing some part of their revenue. The ad valorem tax rate will be a determining factor which can bring a variety of financial effects to the commune budgets. Cadastral value is a separate issue and, as such, will be excluded from the present considerations since it has been tackled by several authors (e.g., see: Mołdoch, 2009). It should be emphasized that the cadastral value will be determined in a process of real estate mass appraisal defined in the Property Management Act. Questions concerning mass appraisal have been discussed by many authors (e.g. see: KRAWCZYK 2009; HOZER, KOKOT 2005).

The paper presents an extended discussion of the findings of studies on the effect of cadastral tax rates on tax burden and commune revenue in Poland (see: GNAT 2016). It focuses on the results of an analysis concerning the influence of various ad valorem property tax rates on the possibility of commune revenue loss. It seems undisputable that local authorities that are likely to face such a loss will not support the real estate taxation reform. In the present paper, several levels of percentage ad valorem property tax rates area analyzed. The rates have been specified so that they can provide communes with revenue from real estate tax at levels of $100 \%, 150 \%$ and $200 \%$ of the present revenue from the tax based on property size. Then, for these rates, the probability of revenue loss in individual geodesic precincts is determined. Such an approach (the analysis of revenue in individual precincts) intends to simulate changes in commune revenue. Further studies may follow up with the analysis of more than one commune. The final stage of this study is a more extensive analysis of changes in the tax burden for such an ad valorem tax rate that would eliminate the risk of revenue loss in individual geodesic precincts. The purpose of this study is to determine the number of communes (precincts) that would face a loss of revenue from real estate taxation depending on the adopted ad valorem tax rate. The analysis covers land subject to real estate taxation. Buildings and premises have been excluded from the analysis.

\section{Methodology}

The execution of the research depends on the appraisal of real estate value subject to taxation. The process of determining the cadastral value is called real estate mass appraisal and is regulated be the provisions of the Property Management Act of 21 August 1997 (the Act) and the Ordinance of the Council of Ministers of 29 June, 2005 on real estate mass appraisal. Article 162.1 of the Act states: "Cadastral values determined in the process of real estate mass appraisal shall account for the differences among individual properties and approach the market value possible to obtain when using generally established rules of mass appraisal". There are two important elements here. Firstly, the Polish legislator points out that the cadastral value should be close to the market value. Secondly, mass appraisal is indicated as the appraisal method. Real estate mass appraisal is a process where the market (cadastral) value of many properties is determined simultaneously. Such an approach requires a specific procedure based on mathematical models. Proposed algorithms of real estate mass appraisal can be found in many publications (e.g. HOZER et al. 1999; CZAJA, 2001; SAWIŁOW 2009). The issue of 
mass appraisal is not exclusively a Polish domain. One can find several works discussing mass appraisal in the context of real estate taxation also in international literature (e.g. PYALEVA, KOLCHENKO 2015). This study uses the procedure of mass appraisal proposed by J. Hozer:

$$
\begin{gathered}
\hat{W}_{r i}=W \hat{W} R_{i} \cdot p o w \cdot C_{b a z} \cdot \prod_{l=1}^{p}\left(1+A_{l}\right) \\
\hat{W} \hat{W} R_{\mathrm{i}}=\frac{\mathrm{C}_{\mathrm{r}_{\mathrm{i}}}}{\mathrm{C}_{\mathrm{h}_{\mathrm{i}}}}
\end{gathered}
$$

where:

$w_{r i} \quad$ - market value of $i$-th property,

pow - plot size,

$C_{b a z}$ - value of $1 \mathrm{~m}^{2}$ of the cheapest (non-developed, agricultural) land in the observed area,

$A_{l} \quad$ - calibrated values of parameters assigned to concrete property attributes (defined on the basis of analyses and diagnoses of the local market; reflecting the impact of individual attributes on property value),

$p \quad$ - number of market characteristics,

$W W R_{i}$ - market value rates,

$C_{r i} \quad$ - property value calculated by a valuer,

$C_{h i} \quad$ - hypothetical value according to the formula:

$$
\mathrm{C}_{\mathrm{h}}=\text { pow } \cdot \mathrm{C}_{\text {baz }} \prod_{\mathrm{l}=1}^{\mathrm{p}}\left(1+\mathrm{A}_{1}\right) \cdot
$$

The study had the character of a simulation. The assumption was that the property tax based on the real estate size will be replaced with the ad valorem property tax. The simulation comprised two main tasks. First, the amount of property tax on urbanized land located in one of the West Pomeranian communes was determined according to a resolution announced by the local commune council in 2016. Thus, the study was based on the estimated rather than real tax burden. What is more, buildings and structures were excluded from the study. Even when the plot of land was built up, this was not taken into account. The study focused solely on plots of land. Second, using the aforementioned Szczecin Algorithm of Real Estate Mass Appraisal, a mass appraisal of plots of land in one commune was performed. Thus, the obtained values were the basis for ad valorem property taxation. The taxation covered 2,337 plots of land. The market value of real estate and its similar cadastral value are determined by a range of market factors and conditions. The Ordinance on real estate mass appraisal outlines (...) the following attributes of land intended for purposes other than agricultural and forest that have an effect on the cadastral value:

- location,

- land use specified in the local land use plan or, in its absence, according to its actual use regime,

- the state of technical infrastructure facilities,

- land development,

- soil class if included in the land registry.

Basing on the collected data about the properties, the following attributes were defined in the course of real estate mass appraisal:

- size - large (over 5,000 m²), medium (ranging between 1000 and $5000 \mathrm{~m}^{2}$ ), small (less than 1000 $\left.\mathrm{m}^{2}\right)$,

- location - unfavorable (parcels located in small towns and villages, and in the outskirts of cities), average (parcels located in cities) and favorable (parcels located in areas regarded as attractive by investors),

- supply lines - absent, partial (usually no sewage system), full,

- shape - bad (difficult to develop; narrow, irregular parcels), good (square or rectangular, easy to develop and use),

- land use - economic, industrial, multi-family residential, single-family residential, commercial. As mentioned in the background, several ad valorem property tax rates were taken into consideration. The specified rates were calculated at levels that would provide the communes with revenue from the 
property value-based tax at $100 \%, 150 \%$ and $200 \%$ of the present revenue from the size-based tax. Tax rates allowing for higher benefits were not analyzed because such rates would lead to a significant (multiple) rise in the tax burden for specific groups of real estate (see: Gnat 2009). Such a situation would definitely cause public outcry in Poland. The ad valorem property tax is the more likely to be socially accepted the less burdensome it is to taxpayers. The study results are presented below.

\section{Empirical study}

The estimated property tax rates and the values of land plots determined in the process of mass appraisal were the basis for predicting the effects of the ad valorem property tax. Then, for the estimated property values and the property tax burden in light of the existing legal regulations, the percentage ad valorem property rates that would guarantee future commune revenue at $100 \%, 150 \%$ and $200 \%$ of their present income were computed. The present property tax burden was estimated according to property tax rates adopted in the given commune in 2016. Basing on the total revenue from property tax, it was established which ad valorem tax rate would bring revenue at $100 \%, 150 \%$ and $200 \%$ of the estimated current income from the existing property tax. The level of $100 \%$ was chosen to find out the potential effects of changing the property tax base while retaining the same proceeds to the commune budget. The choice of the remaining thresholds was made with the assumption that the value-based tax is to provide communes with higher income than size-based property tax.

Table 1

Ad valorem tax rates according to the assumed relation to revenue from size-based property tax in the analyzed commune

\begin{tabular}{cc}
\hline $\begin{array}{c}\text { Revenue from ad valorem tax as percentage } \\
\text { of revenue from size-based property tax }\end{array}$ & Ad valorem percentage tax rate \\
\hline $100 \%$ & $0.36 \%$ \\
\hline $150 \%$ & $0.54 \%$ \\
\hline $200 \%$ & $0.72 \%$ \\
\hline \multicolumn{2}{c}{ Source: own study }
\end{tabular}

The percentage tax rates in Table 1 should not be regarded as a proposal of actual rates because they are closely related with the conditions adopted in the present study. The principal objective of the study is to point out how the change in the tax rate (and not its specific level) influences the risk of revenue loss in communes.

Table 2 shows the percentage of parcels in the analyzed commune for which the tax burden would lessen.

Table 2

The percentage of plots in the analyzed commune whose tax burden would decrease

\begin{tabular}{c|c}
\hline Ad valorem percentage tax rate & $\begin{array}{c}\text { Percentage of plots with lower tax } \\
\text { burden }\end{array}$ \\
\hline $0.36 \%$ & $45 \%$ \\
\hline $0.54 \%$ & $29 \%$ \\
\hline $0.72 \%$ & $22 \%$ \\
\hline
\end{tabular}

Source: own study.

It is clear that the risk of revenue loss in communes cannot be considered negligible. Depending on the adopted percentage ad valorem tax rate, the proportion of parcels with lower tax burden ranges from $22 \%$ to $45 \%$. From a taxpayer's point of view, lower tax burden is perceived in a positive light. From the point of view of commune authorities, however, this is not so obvious. If a commune gives priority to maximizing its revenue, the revenue loss will be regarded as negative. It should also be noted that the adopted tax rates provide revenue that is not lower than that coming from the sizebased tax. This means that the tax burden will rise significantly for a part of the parcels so that the decrease in revenue from other properties can be compensated for. Data in Table 2 show that revenue 
loss can become a real problem for some communes. In order to verify the probability of such a risk, the analysis of changes in revenue in individual commune precincts was conducted. For the purpose of the study, precincts were considered to be the smallest administrative units in the property taxation system. Simplistically, this is intended to simulate the fluctuations in commune revenue from property tax. The commune under analysis consisted of 32 precincts with 13-243 taxable plots of land. Table 3 shows the proportion of parcels in individual precincts whose tax burden would decrease if the size-based property tax was replaced with the value-based one.

Table 3

Proportion of land plots in analyzed commune precincts where revenue from property tax would fall if size-based property tax were to be replaced with value-based tax

\begin{tabular}{|c|c|c|c|}
\hline \multirow[t]{2}{*}{ Precinct No. } & \multicolumn{3}{|c|}{ Ad valorem tax rate } \\
\hline & $0.36 \%$ & $0.54 \%$ & $0.72 \%$ \\
\hline 1 & $100 \%$ & $84 \%$ & $59 \%$ \\
\hline 2 & $100 \%$ & $51 \%$ & $47 \%$ \\
\hline 3 & $100 \%$ & $1 \%$ & $0 \%$ \\
\hline 4 & $100 \%$ & $38 \%$ & $38 \%$ \\
\hline 5 & $100 \%$ & $94 \%$ & $94 \%$ \\
\hline 6 & $100 \%$ & $100 \%$ & $41 \%$ \\
\hline 7 & $100 \%$ & $6 \%$ & $6 \%$ \\
\hline 8 & $100 \%$ & $32 \%$ & $32 \%$ \\
\hline 9 & $100 \%$ & $100 \%$ & $64 \%$ \\
\hline 10 & $100 \%$ & $100 \%$ & $67 \%$ \\
\hline 11 & $100 \%$ & $100 \%$ & $100 \%$ \\
\hline 12 & $98 \%$ & $96 \%$ & $96 \%$ \\
\hline 13 & $93 \%$ & $1 \%$ & $1 \%$ \\
\hline 14 & $93 \%$ & $93 \%$ & $93 \%$ \\
\hline 15 & $82 \%$ & $82 \%$ & $13 \%$ \\
\hline 16 & $80 \%$ & $54 \%$ & $54 \%$ \\
\hline 17 & $63 \%$ & $63 \%$ & $63 \%$ \\
\hline 18 & $62 \%$ & $62 \%$ & $50 \%$ \\
\hline 19 & $56 \%$ & $56 \%$ & $54 \%$ \\
\hline 20 & $42 \%$ & $35 \%$ & $35 \%$ \\
\hline 21 & $21 \%$ & $20 \%$ & $20 \%$ \\
\hline 22 & $21 \%$ & $5 \%$ & $0 \%$ \\
\hline 23 & $5 \%$ & $5 \%$ & $1 \%$ \\
\hline 24 & $0 \%$ & $0 \%$ & $0 \%$ \\
\hline 25 & $0 \%$ & $0 \%$ & $0 \%$ \\
\hline 26 & $0 \%$ & $0 \%$ & $0 \%$ \\
\hline 27 & $0 \%$ & $0 \%$ & $0 \%$ \\
\hline 28 & $0 \%$ & $0 \%$ & $0 \%$ \\
\hline 29 & $0 \%$ & $0 \%$ & $0 \%$ \\
\hline 30 & $0 \%$ & $0 \%$ & $0 \%$ \\
\hline 31 & $0 \%$ & $0 \%$ & $0 \%$ \\
\hline 32 & $0 \%$ & $0 \%$ & $0 \%$ \\
\hline
\end{tabular}

Source: own study. 
The data in Table 3 show that, when we adopt the above tax rates, the total area of some precincts or its considerable part will be charged with ad valorem tax lower than size-based tax. Even if the revenue of the commune as a whole does not fall, the situation may vary in individual precincts. At the lowest value of the analyzed tax rates, one third of the precincts will observe a decreased tax burden levied on the total of local taxable land. As the tax rate increases, the number of such precincts will decrease, but even at the highest analyzed rates, there will be a dozen or so per cent of precincts where over $90 \%$ of land plots will contribute a lower tax. Although, from the taxpayer's point of view, such a situation is advantageous, it may not be equally beneficial for commune budgets. As it has been mentioned before, the replacement of the size-based property tax with the value-based tax will result in shifting tax burden among properties. The adoption of tax rates that are to ensure unchanged or increased commune tax revenue, as such, provides the commune with satisfactory income in global terms, but the changes in revenue in individual precincts may be different. Table 4 shows the percentage changes in revenue from tax levied on plots of land in individual precincts depending on the adopted ad valorem tax rate. In the case of the lowest of the analyzed ad valorem rates, i.e. the rate that provides communes with revenues equal to the property tax currently in force, 21 out of 32 precincts will face a revenue loss ranging from $1 \%$ to over $70 \%$. It thus transpires that the risk of financial loss suffered by communes as a result of a property tax reform is far from marginal. Even at the highest of the analyzed tax rates, a loss of revenue from property tax would be experienced by $25 \%$ of precincts. The results are not representative for the country as a whole. Nevertheless, they show that revenue loss is a problem that cannot be ignored.

Table 4

Percentage change in revenue from land property tax in individual precincts by percentage rate of $a d$ valorem tax adopted in the analyzed commune

\begin{tabular}{|c|c|c|c|}
\hline \multirow[t]{2}{*}{ Precinct No. } & \multicolumn{3}{|c|}{ Ad valorem tax rate } \\
\hline & $0.36 \%$ & $0.54 \%$ & $0.72 \%$ \\
\hline 1 & $-73 \%$ & $-59 \%$ & $-45 \%$ \\
\hline 2 & $-56 \%$ & $-34 \%$ & $-12 \%$ \\
\hline 3 & $-22 \%$ & $17 \%$ & $56 \%$ \\
\hline 4 & $-57 \%$ & $-36 \%$ & $-14 \%$ \\
\hline 5 & $-59 \%$ & $-39 \%$ & $-18 \%$ \\
\hline 6 & $-65 \%$ & $-47 \%$ & $-30 \%$ \\
\hline 7 & $-15 \%$ & $27 \%$ & $70 \%$ \\
\hline 8 & $-34 \%$ & $-1 \%$ & $32 \%$ \\
\hline 9 & $-50 \%$ & $-24 \%$ & $1 \%$ \\
\hline 10 & $-52 \%$ & $-28 \%$ & $-4 \%$ \\
\hline 11 & $-57 \%$ & $-35 \%$ & $-13 \%$ \\
\hline 12 & $-40 \%$ & $-11 \%$ & $19 \%$ \\
\hline 13 & $-11 \%$ & $34 \%$ & $79 \%$ \\
\hline 14 & $-69 \%$ & $-53 \%$ & $-38 \%$ \\
\hline 15 & $-38 \%$ & $-6 \%$ & $25 \%$ \\
\hline 16 & $-49 \%$ & $-23 \%$ & $2 \%$ \\
\hline 17 & $-34 \%$ & $-1 \%$ & $32 \%$ \\
\hline 18 & $-29 \%$ & $7 \%$ & $42 \%$ \\
\hline 19 & $-27 \%$ & $9 \%$ & $45 \%$ \\
\hline 20 & $-20 \%$ & $20 \%$ & $60 \%$ \\
\hline 21 & $-1 \%$ & $48 \%$ & $97 \%$ \\
\hline 22 & $49 \%$ & $124 \%$ & $199 \%$ \\
\hline 23 & $61 \%$ & $141 \%$ & $222 \%$ \\
\hline
\end{tabular}




\begin{tabular}{c|ccc}
\hline Precinct No. & \multicolumn{3}{|c}{ Ad valorem tax rate } \\
\hline & $0.36 \%$ & $0.54 \%$ & $0.72 \%$ \\
\hline 24 & $113 \%$ & $219 \%$ & $326 \%$ \\
\hline 25 & $30 \%$ & $96 \%$ & $161 \%$ \\
\hline 26 & $59 \%$ & $139 \%$ & $218 \%$ \\
\hline 27 & $34 \%$ & $100 \%$ & $167 \%$ \\
\hline 28 & $43 \%$ & $115 \%$ & $187 \%$ \\
\hline 29 & $33 \%$ & $100 \%$ & $167 \%$ \\
\hline 30 & $49 \%$ & $123 \%$ & $198 \%$ \\
\hline 31 & $36 \%$ & $104 \%$ & $172 \%$ \\
\hline 32 & $41 \%$ & $112 \%$ & $182 \%$ \\
\hline
\end{tabular}

Source: own study.

There is no doubt that the computed loss in revenue is related to the value of properties. Properties characterized by low value will generate a deeper "revenue capacity decline" to the commune than highly valuated ones. Tables 5-9 show the proportion of plots in the analyzed commune that would yield lower revenue after the property tax reform by their marketable attributes.

Table 5

Percentage of land plots that would yield lower revenue by size

\begin{tabular}{c|ccc}
\hline Property attribute & \multicolumn{3}{|c}{ Ad valorem tax rate } \\
\hline Size & $0.36 \%$ & $0.54 \%$ & $0.72 \%$ \\
\hline large & $76 \%$ & $63 \%$ & $56 \%$ \\
\hline medium & $60 \%$ & $34 \%$ & $27 \%$ \\
\hline small & $31 \%$ & $22 \%$ & $16 \%$ \\
\hline
\end{tabular}

Source: own study.

Table 6

Percentage of plots of land that would yield lower revenue by location

\begin{tabular}{c|ccc}
\hline Property attribute & \multicolumn{3}{|c}{ Ad valorem tax rate } \\
\hline Location & $0.36 \%$ & $0.54 \%$ & $0.72 \%$ \\
\hline unfavorable & $95 \%$ & $58 \%$ & $47 \%$ \\
\hline average & $60 \%$ & $34 \%$ & $30 \%$ \\
\hline favorable & $24 \%$ & $19 \%$ & $11 \%$ \\
\hline
\end{tabular}

Source: own study.

Table 7

Percentage of plots of land that would yield lower revenue by the level of supply line development

\begin{tabular}{c|ccc}
\hline Property attribute & \multicolumn{3}{|c}{ Ad valorem tax rate } \\
\hline supply lines & $0.36 \%$ & $0.54 \%$ & $0.72 \%$ \\
\hline fully developed & $61 \%$ & $28 \%$ & $24 \%$ \\
\hline partly developed & $38 \%$ & $30 \%$ & $22 \%$ \\
\hline
\end{tabular}

Source: own study. 
Percentage of plots of land that would yield lower revenue by plot shape

Table 8

\begin{tabular}{c|ccc}
\hline Property attribute & \multicolumn{3}{|c}{ Ad valorem tax rate } \\
\hline Plot shape & $0.36 \%$ & $0.54 \%$ & $0.72 \%$ \\
\hline bad & $86 \%$ & $76 \%$ & $65 \%$ \\
\hline good & $41 \%$ & $24 \%$ & $18 \%$ \\
\hline
\end{tabular}

Source: own study.

Table 9

Percentage of plots of land that would yield lower revenue by the zoning of property

\begin{tabular}{c|ccc}
\hline Property attribute & \multicolumn{3}{|c}{ Ad valorem tax rate } \\
\hline $\begin{array}{c}\text { Zoning of } \\
\text { property }\end{array}$ & $0.36 \%$ & $0.54 \%$ & $0.72 \%$ \\
\hline economic & $100 \%$ & $98 \%$ & $80 \%$ \\
\hline industrial & $100 \%$ & $44 \%$ & $20 \%$ \\
\hline multi-family & $25 \%$ & $3 \%$ & $1 \%$ \\
\hline single-family & $10 \%$ & $2 \%$ & $0 \%$
\end{tabular}

Source: own study.

In all the cases, there is a regularity in the fact that the weaker the attribute, the higher the percentage of plots in a given category that would generate lower revenue from the property tax. The communes where the majority of land plots are characterized by weak variants of attributes specified in the process of mass appraisal are more likely to suffer a revenue loss resulting from the property tax. Their local authorities will be more inclined to protest against the tax reform or to demand the maximum ad valorem tax rate which will secure the desired earnings. And this is where another problem arises. If the percentage tax rate is adopted at the level that will prevent revenue loss in all communes, in communes with a majority of land properties with good attributes, the property tax burden will rise considerably. This is likely to happen, provided of course that the current tendency of commune councils to apply tax rates that are as close to the maximum as possible. The opposite situation will mean more competition among communes and using lower ad valorem tax rates in order to attract new investors or residents, or to maintain existing ones. To illustrate the changes in tax burden, one more value-based tax rate was taken into consideration in this study, i.e. a rate which would ensure that the revenue from property tax rate will not fall in any precinct. Under the above assumptions, such a tax rate amounts to $1.4 \%$ of property value. In such a case, the revenue would rise from $7 \%$ to $700 \%$ in all of the precincts. There is no doubt that, in precincts with the highest revenue rise, some cases of a dramatic increase in tax burden would appear. In the analyzed commune, a higher tax would be levied on over $95 \%$ of plots. For almost one third of land properties, the tax would rise at least fivefold in comparison to the size-based tax and the average tax burden would increase by over $300 \%$. This means that the value-based tax rate that ensures satisfactory revenue for communes where land properties have predominantly weak marketable attributes would simultaneously lead to a considerable increase in tax burden in those communes containing land plots with better attributes.

\section{Conclusion}

The paper presents the findings of a study on the risk of decreased commune revenue from property tax. What results from the study is that, in contrast to popular belief, a considerable rise in revenue is not a foregone conclusion. The adoption of an ad valorem tax rate that would prevent a marked property tax burden levied on high value properties entails the risk of revenue loss in communes with precincts where the marketable attributes of properties are disadvantageous. Communes with properties with predominantly poorly mass appraised attributes will object to the property tax reform. In this context opting for the ad valorem property tax rate adds another dimension to the problem. Beside the problem of placating taxpayers protesting against increased tax burden, another group may 
appear - communes that may suffer adverse financial effects as a consequence of the reformed tax. This means that further studies on the potential consequences of introducing value-based property tax need to be carried out in order to identify other aspects that should be taken into account in the course of debates and decision-making concerning the real estate taxation system.

\section{References}

CzAJA J., 2001, Methods of Estimating Market and Cadastral Property Value (in Polish: Metody szacowania wartości rynkowej i katastralnej nieruchomości), Komp-system, Kraków.

ETEL L., DowgIER R., 2013, Local Taxes and Charges - Time for a Change (in Polish: Podatki i optaty lokalne czas na zmiany), Temida 2, Białystok.

ETEL L. (ed), 2003, European Systems of Property Taxation (in Polish: Europejskie systemy opodatkowania nieruchomości), Kancelaria Sejmu RP, Warszawa.

GŁuszczaK M., MARONA B., 2015, Cadastral Tax. Economic Conditions for Property Tax Reform (in Polish: Podatek katastralny. Ekonomiczne uwarunkowania reformy opodatkowania nieruchomości), Wydawnictwo Poltext, Warszawa.

GNAT S., Analysis of the effects of replacing current property tax with ad valorem property tax in a sample municipality, Folia Oeconomica Stetinensia, 2009, no. 8(16).

GNAT S., 2016, Size-based vs Cadastral System of Property Taxation - Simulation of Some Fiscal Effects (in Polish: Powierzchniowy a katastralny system opodatkowania nieruchomości - symulacja wybranych skutków fiskalnych), Annales Universitatis Mariae Curie-Skłodowska Sectio H. Oeconomia, Vol. 50 Number 1.

Hełdak, M., 2014, Stacherzak, A.; Baumane, V., Real Estate Value Tax Based on the Latvian Experience, Real Estate Management and Valuation, Vol. 22 Issue 4.

HOZER J., FORYŚ I., ZWOLANKOWSKA M., KOKOT S., KUŹMIŃSKI W., 1999, Econometric Algorithm of Land Property Mass Appraisal (in Polish: Ekonometryczny algorytm masowej wyceny nieruchomości gruntowych), Uniwersytet Szczeciński, Stowarzyszenie Pomoc i Rozwój, Szczecin.

Hozer J., KоKOт S., 2005, Problems of Property Mass Appraisal in Poland (in Polish: Problemy powszechnej taksacji nieruchomości w Polsce), Zeszyty Naukowe Uniwersytetu Szczecińskiego, Studia i Prace Wydziału Nauk Ekonomicznych i Zarządzania, No 16.

Krawczyk M., 2009, Property Mass Appraisal - Its Essence and Importance (in Polish: Powszechna taksacja nieruchomości - istota i znaczenie), Ruch Prawniczy, Ekonomiczny i Socjologiczny, z. 3.

MaronA B., 2006, Property Taxation System in Poland Compared to Some European Countries (in Polish: System opodatkowania nieruchomości w Polsce na tle rozwiązań w wybranych krajach europejskich), Zeszyty Naukowe Akademii Ekonomicznej w Krakowie nr 703, Kraków.

MikeselL, J.L.; ZORN, C.K.; KRUPA, O., 2007, Cadastral Valuation for the Land Tax in the Russian Federation: The New Market-Informed Valuation System, Journal of Property Tax Assessment \& Administration, Vol. 4, Issue 3

MoŁdoch J., 2009, Cadastral Valuation in Conditions of Polish Economy (in Polish: Wartość katastralna w realiach polskiej gospodarki), Studia i Materiały Towarzystwa Naukowego Nieruchomości, Vol. 17, No 1.

PIEKUT J., 2014, Advantages and Disadvantages of Cadastral Property Tax Introduction (in Polish: Wady $i$ zalety wprowadzenia podatku katastralnego), Kwartalnik Naukowy Uczelni Vistula, No 3(41).

PINDYK E., 2016, Effects of Changes in Property Tax on Natural Persons on Commune Budget (in Polish: Wptyw zmian systemu opodatkowania nieruchomości od osób fizycznych na budżet gminy), Research Papers of the Wroclaw University of Economics / Prace Naukowe Uniwersytetu Ekonomicznego we Wroclawiu., Issue 451.

POLNY L., 2014, Prediction Cadastral Tax Implementation in the Aspect of Experience Other Countries, Geomatics And Environmental Engineering, Vol. 8, No. 4.

PyaleVA A., KolchenKo O., 2015, Application of Assessment Approaches and Methods for the Property Cadastral Appraisal, Regional Economics, Issue 16,

Ordinance of the Council of Ministers of 29 June 2005 on real estate mass appraisal (Dz. U. of 2005, No 131, item 1092).

SAWIŁOW E., 2009, Analysis of Selected Methods of Modelling Property Cadastral Value (in Polish: Analiza wybranych metod modelowania wartości katastralnych nieruchomości), Acta Scientarium Polonorum, Geodesia et Descriptio Terrarum 8(2). 
Sawiłow E., Application of Multi-dimensional Comparative Analysis for Cadastral Valuation (in Polish: Zastosowanie metod wielowymiarowej analizy porównawczej dla potrzeb ustalania wartości katastralnych), „Studia i Materiały Towarzystwa Naukowego Nieruchomości” 2009, Vol. 17, No 1.

The Property Management Act of 21 August 1997 (Dz. U. of 1997, No 115, item 741 with amendments).

Wołowiec T., Reform of Polish Property Valuation System as a Chance for Stimulation of Local and Regional Government Development (in Polish: Reforma systemu opodatkowania nieruchomości w Polsce szansa pobudzenia rozwoju lokalnego i regionalnego samorzadów terytorialnych), „Studia Regionalne i Lokalne” 2003, No 4(14). 